\title{
7 ）小柴胡湯薬効成分による培養ヒト肝癌細胞に 対する増殖抑制効果についての検討
}

\author{
山口大学医学部第一内科学教室 \\ 李 千, 沖田極 \\ 山口大学医学部第二病理学教室 \\ 村上知之, 高橋学
}

(平成 4 年 7 月 27 日受稿)

Key words: Sho-saiko-to, Human hepatoma cells (HuH-7)

緒 言

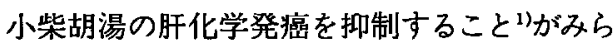
れてから，そのメカニズムを解明するため，わ れわれは小柴胡湯の成分としての Baicalein, Baicalin, Saikosaponin-a, $-c$, Ginsenoside $\mathrm{Rb}_{1}, \mathrm{Rg}_{1}$ のヒト培養肝癌細胞に対する影響につ いて検討した。

\section{材 料と方 法}

对数增殖期の培養七ト肝癌細胞を用い, GIT 培地で $5 \% \mathrm{CO}_{2}, 37^{\circ} \mathrm{C}$ の条件下で継代培養した。 薬剤としては，小柴胡湯に含まれる Baicalein, Baicalin, Saikosaponin-a, -c, Ginsenosaide $\mathrm{Rb}_{1} ， \mathrm{Rg}_{1}$ を使用した。 まず，DMSO で溶解し て stoch solution を作成し, 細胞継代培羕の24 時間目に, 薬剤添加し，24時間ごとに新しい薬 剤添加培養液を交換した，対照には，薬剤無添 加のものと DMSOのみ加えたものを使用した. そして，24時間ごとに細胞数を conlter counter (conlter electronics lnc. USA）にて算定し, 細胞增殖曲線を描いた，同時に，細胞を 0.2 TritonX-100により裸核化し, RNase 添加後, PIでDNA染色を行い, FACScan(Becton Dickinson，USA）によって測定した。また，細胞動 態をDNA 合成能の面から検討するため, 細胞を $\mathrm{BrdU}$ 短時間標識を行った。すするち, 標識細

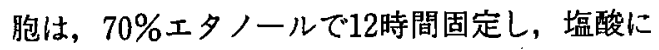

よるDNA 単鎖化処理後, 通常の蛍光抗体間接 法にて核内 BrdU を染色し, FACS Analyza (Becton Dickinson, USA) で解析を行った. また，細胞の生死の確認のために，Pl を用いて dye-exdusion test を行った.

なお，24時間ごとに，各実験群の培盖液中の AFP 濃度を RIA 法で測定した。

\section{結果および考察}

ヒト肝癌細胞に対して, Baicaleinの濃度依存 的な增殖抑制効果が明らかであった. $10 \mu \mathrm{g} / \mathrm{ml}$ 以 上の濃度で, 増殖抑制効果を認め, $50 \mu \mathrm{g} / \mathrm{ml}$ では， 增殖抑制効果が顕著であった．また，その抑制 機序は, 細胞周期非依存性に細胞回転を遅らせ, かつ DNA 合成速度を低下させることが解明さ れた.

Baicalin も Baicalein とほぼ同様の増殖抑制 初果をもたらした. Baicalinには，成分として， Baicalein と wogonin が各50\%ずつ含まれる2). このことが, Baicalinが Baicaleinの半量の効 果と一致することの理由であろう.

Saikosaponin-aでは，濃度依存性に增殖を抑 制し， $30 \mu \mathrm{g} / \mathrm{ml} 24$ 時間 $65 \%, 50 \mu \mathrm{g} / \mathrm{ml} 24$ 時間では, $100 \%$ 死細胞であった．薬郕投与30分後から， 死細胞は出現し，形態的には核が浱縮し，胞体 が腫大した。このような形態変化は，他の薬剤 では観察されなかった。死細胞の DNA 量は， 生細胞よりも小さく測定されたものと，各細胞 
周期の比率は生細胞とほぼ同じであったことか ら, 殺細胞効果は, 細胞周期非依存性であると 考えられてきた。なお,生細胞の DNA histogram のパターンは, 経時的に変化せず, $\mathrm{S}$ 期細胞の ほとんどが DNA 合成を行っていたことから， DNA 合成能の培失と細胞形態の変化は, 細胞の 死とほぼ同時に起こると考えられた。

それに，細胞增殖の抑制に従って，培養液中 に分泌されている AFP 量も著明に減少し, 細 胞增殖と AFP 産出との間に密接な関係が示唆 されている。これは, 臨床治療においても，経 験されるところであり 尚, 今回, Baicalein, Baicalin と Saikosaponin-a 処理した HuH- 7 細胞の場合も同様現象がみられた。

今までの小柴胡湯の抗腫瘍作用は, 生体全体 に作用し, 各種生理機能, 代謝の活性化を通じ $\tau$, 生体の生物学的反応性の変換を誘導し, 結 果として, 癌に対する宿主の非特異的な低抗性 を増大させると考えられて来た。しかし，今回 の実験によって，それらの作用ばかりでなく， 癌細胞に直接作用し, 増殖抑制と殺細胞効果を
もたらすことも示唆された。 これらの効果が, 肝細胞癌に対する小柴胡湯の化学予防作用の背 景に存在することが十分に考えられた：また， 今回の結果から, 癌治療の面でも, Baicalein ゃ Saikosaponin-a 等薬効成分を局所投与する方法 が期待された.

結語

1. Baicalein, Baicalin は細胞堌殖を濃度依 存性，かつ細胞周期非依存性に抑制した。 Baicalein $50 \mu \mathrm{g} / \mathrm{ml}$, Baicalin $100 \mu \mathrm{g} / \mathrm{ml}$ の濃度で 24時間後の細胞数の増加がほぼ完全に止った。

2. Saikosaponin-a は, 殺細胞効果が認めら れ，それは濃度依存性，かつ細胞周期非依存性 であった。死細胞には，核濃縮が高度であった。

3. Baicalein, Baicalin Saikosaponin-a に よる細胞增殖抑制は, AFP 産生抑制を伴った。

4. Saikosaponin-c, Ginsenoside $\mathrm{Rb}_{1}, \mathrm{Rg}_{1}$ は細胞增殖抑制効果がみられなかった。

1) 沖田 極, 他：消化器科 (1990) 12, 152.

2）久保木憲人，他：薬局（1963）14，968.

3) Sasaki K, et al. : Jpn Cancer Res (1986) 77, 264. 